\title{
Determinants of foreign direct investment from EU-15 Countries in Poland
}

Andrzej Cieślik

To cite this article: Cieślik, A. (2019). Determinants of foreign direct investment from EU-15 Countries in Poland. Central European Economic Journal, 6(53), 39-52.

DOI: 10.2478/ceej-2019-0007.

To link to this article: https://doi.org/10.2478/ceej-2019-0007 


\title{
Central European Economic Journal
}

\author{
Andrzej Cieślik1 (iD) \\ 1 Faculty of Economic Sciences, University of Warsaw, Długa 44/50, 00-241 Warszawa, Poland, corresponding author: cieslik@wne.uw.edu.pl
}

\section{Determinants of foreign direct investment from EU-15 Countries in Poland}

\begin{abstract}
During the last two decades, Poland has become a large recipient of inward foreign direct investment (FDI). This article uses standard panel data techniques to study empirically the determinants of inward FDI in Poland during the period 1996-2015 made by multinational enterprises coming from the old European Union (EU)-15 member states. The estimated specification is derived from the knowledge-capital (KC) model and includes two types of capital: human and physical. The assembled empirical evidence points to the horizontal motive as the primary reason for undertaking FDI in Poland by multinational firms based in the old EU-15 member states. Moreover, the KC model does not seem to explain better the pattern of inward FDI in Poland compared to the standard ad hoc gravity model of international capital mobility.
\end{abstract}

Keywords: factor endowments, foreign direct investment, EU-15 member states, panel data analysis, Poland

JEL Codes: F23, P33

\section{Introduction}

Multinational enterprises (MNEs) play an important role in the ongoing process of globalization of the world economy. While many theories have been proposed to explain the emergence of MNEs, two main reasons why a firm should internationalize its production processes can be identified in the theoretical literature: market seeking and efficiency seeking (Markusen, 2013). According to the first one, MNEs are vehicles to overcome distance and lower costs of foreign markets access. Foreign direct investment (FDI) undertaken by MNEs to serve a local market in a host country is called horizontal FDI. This kind of FDI refers to producing abroad the same or similar products as in the home country. According to the second one, firms internationalize their production and become MNEs to get inputs at a lower cost. FDI undertaken with the aim of reducing production costs is called vertical FDI. This kind of FDI involves international fragmentation of production processes and location of each stage of production in a country where the factors used intensively in that particular stage are relatively cheap. These two alternative reasons for FDI have very different empirical and practical implications.

Traditionally, most empirical work on MNE activity has focused on the US firms operating abroad as well as inward FDI in the US (Bloningen, Davies, \& Head, 2003; Braconier, Norback, \& Urban, 2005; Davies, 2008; Bergstrand \& Egger, 2013). However, more recently determinants of multinational activity have also been intensively studied for the group of the so-called emerging economies that managed to attract large amounts of inward FDI. In particular, in the last two decades, Poland has become an attractive host country for the location of inward FDI, most of which comes from the developed West European economies. As the majority of FDI in Poland originates from the old European Union (EU)-15 countries, the main goal of this article is to validate the predictions of competing theoretical models and identify the main reasons for 
inward FDI in Poland using bilateral panel dataset on FDI from the old EU-15 member states covering the period 1996-2015.

The structure of this paper is as follows. The next section provides the review of the relevant literature on FDI determinants and discusses empirical implications of competing theoretical frameworks. Subsequently, data sources of the empirical methodology are discussed. Finally, we show and interpret our estimation results. The article ends with final conclusions and guidelines for future studies.

\section{Literature review}

Formal theoretical modeling in the so-called new trade theory that emerged in the early 1980s provided a set of modeling tools that proved very useful in studying the emergence of MNEs. This initiated the development of the so-called new theory of multinational enterprise (NTMNE) starting from the mid-1980s. To explain FDI between similar countries, a number of models of horizontally integrated MNEs were developed. Initially, these models were based on partial equilibrium frameworks and assumed identical factor endowments across countries, and later, they were extended to general equilibrium settings.

The early examples of this approach include models developed by Krugman (1983) and Markusen (1984) that were later extended, inter alia, by Horstmann and Markusen (1987); Brainard (1993a); Markusen and Venables (1998, 2000); Helpman, Melitz, and Yeaple (2004); Sinha (2010); Collie (2011); and more recently by Cieślik (2013, 2015a, 2015b, 2016, 2018) and Cieślik and Ryan (2012). Theoretical modeling of horizontally integrated MNEs usually involves a tradeoff between the saving in variable costs of exporting, such as transport costs and tariffs, and the additional fixed costs of setting up a new plant in the host country. The theory predicts that given moderate to high trade costs, horizontally integrated MNEs prevail in equilibrium when countries are similar in size and in relative factor endowments.

With falling transportation and communication costs, an increasing part of MNE activity is explained by the cost-reduction motive. Vertically integrated MNEs split up their production processes into separate fragments that can be located in different countries where the factors of production they intensively use are relatively cheap. Theoretical modeling of vertically integrated MNEs hinges on the idea that different segments of the production process have different input requirements so it may be profitable to locate each segment where the factors used intensively in that stage are relatively cheap. The first models of a verticallyintegrated MNE were developed by Helpman (1984) and Helpman and Krugman (1985). These models were later extended by, inter alia, Zhang and Markusen (1999), Markusen and Venables (2000), and Markusen (2002).

Initially, horizontal and vertical models of MNEs were regarded as two separate strands in the literature. The next step in the development of the NTMNE was focused on combining the horizontal and vertical approaches into an integrated framework. In this framework, firms could choose between national, horizontal, and vertical strategies. This synthesis was done by Markusen (2002) who called this integrated framework the knowledgecapital (KC) model. According to this model, national exporting firms dominate when countries are similar in economic size and in factor proportions, and trade costs are low. Horizontally integrated MNEs dominate when countries are similar in economic size and in factor proportions, and trade costs are high. Alternatively, vertically integrated MNEs dominate if countries are similar in size but dissimilar in factor proportions, and trade costs are low.

In the subsequent years, the $\mathrm{KC}$ model has been extended in many directions. These extensions include, inter alia, studies by Bergstrand and Egger (2007, 2013), Markusen and Strand (2009), Markusen and Stähler (2011), and Chen, Horstmann, and Markusen (2012). The most important recent extension of the $\mathrm{KC}$ model is the incorporation of physical capital in addition to human capital. This allows a direct comparison of the KC model with the earlier models of horizontally and vertically integrated MNEs in which differences in factor proportions were determined only by physical capital to labor ratios.

Formal empirical studies that attempted to test the predictions of the NTMNE did not start until the early 1990s. Initially, they focused on US multinationals while FDI from other countries received relatively less attention. In particular, these studies were initiated by 
Brainard (1993b, 1997) who tested competing models of horizontally and vertically integrated MNEs. It was found that the majority of US MNEs were integrated horizontally, and not vertically. However, Carr, Markusen, and Maskus (2001) estimated specifications directly derived from the KC model and found that US MNEs were integrated not only horizontally but also vertically. Since then the determinants of FDI flows have been widely investigated also in other countries.

The empirical determinants of inward FDI into the whole group of Central and East European economies were studied by a number of authors including, inter alia, Lansbury, Pain, and Smidkova (1996); Brenton, Di Mauro, and Lucke (1999); Benacek, Gronicki, Holland, and Sass (2000); Resmini (2000); Garibaldi, Mora, Sahay, and Zettelmeyer (2001); Bevan and Estrin (2004); Carstensen and Toubal (2004); Cieślik and Ryan (2004); Baniak, Cukrowski, and Herczyński (2005); Gorbunova, Infante, and Smirnova (2012); Wach and Wojciechowski (2016); and more recently also Ascani, Crescenzi, and Iammarino (2017); Stack, Ravishankar, and Pentecost (2017); and Tang (2017). However, the empirical studies for individual CEECs are more scarce.

In particular, determinants of MNE activity in Poland were studied by Cieślik (1996, 2006, 2017, 2019a, 2019b, 2019c) and Torrisi, Delaunay, Kocia, and Lubieniecka (2009). However, with the exception of the studies by Cieślik (1996, 2006, 2017, 2019a, 2019b, 2019c), the previous studies made no attempts to test empirically the predictions derived directly from the NTMNE and discriminate between competing models. Moreover, the previous studies often used the number of firms with foreign capital participation as a dependent variable, while this study uses the actual data on the FDI position collected from the annual reports of the National Bank of Poland (NBP) as a measure of FDI. Thus, further research on the determinants of FDI in Poland using alternative measures of foreign involvement would be definitely of interest.

Moreover, it seems clear that the process of integration into the EU should have a significant impact on the amount of FDI located in Poland. This is mostly due to the fact that through a gross domestic product (GDP) growth and reduction in trade costs, it led to a substantial expansion of market size. However, at the same time, the accession to the EU reduced the differences between Poland and the other EU member countries in terms of unit labor costs. This in turn could decrease the inflows of vertical FDI and increase inward horizontal FDI.

\section{Data sources and empirical methodology}

The literature surveyed in the previous section indicates how FDI can be related to individual country-pair characteristics. The characteristics that affect the amount of FDI between the source and host countries in pure horizontal and vertical models are also present in the hybrid model. Therefore, horizontal and vertical models can be regarded as two extreme cases of the more general KC model. The empirical equation derived directly from this model can be estimated using panel data for Poland over the period 1996-2015. However, the expected effects of particular country-pair characteristics can differ across particular models. Therefore, validating which investment motive better explains the cross-country pattern of FDI in Poland can be done by evaluating the signs and statistical significance of the estimated coefficients on these characteristics.

In particular, the similarity in economic size and in relative factor endowments between Poland and the old EU-15 member countries is the main explanatory variable that allows distinguishing between different theoretical models. The pure horizontal and KC models predict a negative relationship between FDI and differences in the economic country size between the source and host countries. In contrast, according to the pure vertical model, similarity in country size should not play any role. Hence, the positive and statistically significant coefficient on the variable measuring similarity in country size can be expected if the market access motive is important and not significant otherwise.

The similarity in relative country size can be measured using the size dispersion index (SDI) developed by Helpman (1987). In particular, he defined the index of size similarity for a group (I) of trading partners as follows: 
$\operatorname{SIMILARITY}_{1}=1-\sum_{j \in \mathrm{I}}\left(s_{j}\right)^{2}$

where $s j$ is country $j$ 's share of group I's GDP. It is maximized when all countries are equal in size.

In our empirical analysis, we use a bilateral version of this index. Therefore, the Helpman's SDI for each pair of countries in our study is calculated as follows:

$\mathrm{SDI}_{i j}=1-\left(\frac{\mathrm{GDP}_{i}}{\mathrm{GDP}_{i}+\mathrm{GDP}_{j}}\right)^{2}-\left(\frac{\mathrm{GDP}_{j}}{\mathrm{GDP}_{i}+\mathrm{GDP}_{j}}\right)^{2}$

where GDP $i$ and GDP $j$ are respectively country $i$ 's GDP and country j's GDP.

The value of this index ranges between 0 and $1 / 2$. The value of SDI is positively related to similarity in country size and reaches its maximum when countries are of equal size. SDI is calculated using data on outputside real GDP at chained purchasing power parity (PPP) rates and expressed in constant 2011 US dollars for Poland and particular old EU member states. These data come from the Penn World Table (PWT) 9.0 available online at www.ggdc.net/pwt. ${ }^{1}$

In addition, the pure horizontal model predicts that FDI in the host country should be decreasing with rising differences in relative factor endowments, while the pure vertical and the KC models suggest an opposite relationship. Therefore, the estimated parameters on the measures of differences in relative factor endowments variable should be positive and statistically significant if the efficiency seeking motive is more important than the market access motive and negative and statistically significant otherwise.

The differences in relative factor endowments between Poland and EU-15 investment partner countries are measured using differences in both human and physical capital per worker. The differences in physical capital endowments (K-DIFF) are calculated using the national capital stocks expressed in PPPs in constant 2011 US dollars and the number of workers employed. The differences in human capital endowments (H-DIFF) are calculated using the human capital indexes for the source and host countries that are based on the average

1 See Feenstra, Inklaar, and Timmer (2015) for detailed description of the Penn World Table. years of schooling and returns to education. The data necessary to calculate differences in relative human and physical capital endowments come from the PWT 9.0.

Moreover, in addition to the measures of factor proportions and SDI that are a part of our identification strategy, we also control for the effects of other factors predicted by the theory. In particular, we control for the summation of Poland's and the home country's GDPs (SUM). According to all theoretical models surveyed in the previous section, the combined market size of investment partners should be positively related to the amount of FDI in the host country. Therefore, we should expect a positive sign of the estimated coefficient on the SUM variable. The SUM variable is calculated using the same GDP data that was used previously to calculate SDI.

Finally, in order to control for the potential effect of trade costs, we include physical geographic distance (DISTANCE). ${ }^{2}$ The theory does not provide clear predictions concerning the effect of distance on FDI in the host country, and its effect must be determined empirically. Nevertheless, following the previous empirical studies surveyed in the literature review section, a negative effect should be expected. The physical geographic distance is measured "as the crow flies" distance between the capitals of the EU-15 member states and the capital city of Poland (Warsaw), and it is expressed in kilometers. These distance data are available online at http:/ / www.indo.com/distance. In addition, in order to control for business cycle and policy changes such as joining the EU, individual time specific effects are included. In order to avoid a potential endogeneity problem, absolute and relative country size variables as well as the measures of differences in relative factor endowments are one period lagged.

The definitions of explanatory variables and their summary statistics are summarized in Table 1, while the calculated values of the correlations between the explanatory variables used in the empirical study are reported in Table 2 . These results show that the

2 The tariffs on manufactured products in trade between Poland and the EU-15 were eliminated in the second half of the 1990s as a result of the association agreement with the EU signed in 1991. This means that already long before Poland's accession to the EU in 2004, trade with the old EU-15 member states was mostly free. See for details Cieślik (2007) and Cieślik and Hagemejer (2011). 
Tab. 1: Definitions and summary statistics of explanatory variables

\begin{tabular}{llllll}
\hline Explanatory variable & Definition & Mean & Std. dev. & Min & Max \\
\hline H-DIFF & Human capital per worker difference & 0.260 & 0.408 & 0.001 & 0.900 \\
\hline K-DIFF & Capital per worker difference & $20,0143.400$ & $72,901.280$ & $85,208.190$ & $421,443.300$ \\
\hline SDI & Helpman's size dispersion index & 0.377 & 0.097 & 0.092 & 0.500 \\
\hline SUM & $\begin{array}{l}\text { Sum of parent country and Poland's } \\
\text { GDPs }\end{array}$ & $1,543,024.000$ & $979,411.400$ & $439,640.900$ & $4,678,112.000$ \\
DISTANCE & $\begin{array}{l}\text { Geographic distance of each parent } \\
\text { country's capital city from Warsaw }\end{array}$ & 1292.267 & 609.981 & 515 & 2756 \\
\hline
\end{tabular}

Std. dev., standard deviation; Min, minimum; Max, maximum; GDP, gross domestic product. Source: Own elaboration.

Tab. 2: Correlations between explanatory variables

\begin{tabular}{llllll}
\hline Variable & H-DIFF & K-DIFF & SDI & GDPSUM & DISTANCE \\
\hline H-DIFF & 1 & -0.193 & -0.006 & 0.265 & 0.599 \\
\hline K-DIFF & 1 & -0.126 & 0.155 & -0.041 \\
\hline SDI & & 1 & -0.100 & 0.117 \\
\hline SUM & & & 1 & -0.085 \\
\hline DISTANCE & & & & 1
\end{tabular}

Source: Own elaboration.

explanatory variables are not strongly correlated with each other.

The inward FDI stock in Poland is measured using the data on the FDI position obtained from the annual reports of the NBP entitled "Foreign Direct Investment in Poland" published on a regular basis since 2003. The FDI position is the net sum of equity and debt instruments, and the equity constitutes its major part. The first NBP report was published in 2003 and included the statistical data also for earlier years starting from 1996. Hence, the starting year of our sample is 1996. The last year of our sample is 2015, which is determined by the data availability for our explanatory variables obtained from the PWT 9.0. Therefore, our sample contains old EU-15 countries during the period 1996-2015, which yields a panel of 300 observations.

In the last year of our sample (2015), the total inward FDI stock in Poland amounted to $\$ 185,986.4$ million. The top three source countries among the EU-15 countries in 2015 were, respectively, the Netherlands with \$
34,561.3 million, Germany with \$28,161.6 million, and Luxembourg with $\$ 4,224.4$ million.

The relationships between FDI and independent variables derived from the theory are estimated using the standard techniques of panel data econometrics including fixed and random effects estimators. The estimated equation in the generalized form is expressed as follows:

$$
\begin{aligned}
& \ln \mathrm{FDI}_{i j t}=\alpha_{0}+\alpha_{1} \ln \left(Y_{i t}+Y_{j t}\right)+\alpha_{2} \ln \left(1-s_{i t}^{2}-s_{j t}^{2}\right)+ \\
& +\alpha_{3} \ln \left|K_{i t} / L_{i t}-K_{j t} / L_{j t}\right|+\alpha_{4} \ln \left|H_{i t} / L_{i t}-H_{j t} / L_{j t}\right| \\
& +\alpha_{5} \ln \operatorname{DISTANCE}_{i j}+v_{i j}+u_{t}+\varepsilon_{i j t}
\end{aligned}
$$

where FDI ijt is a bilateral inward FDI stock from country $i$ to country $j$ in year $t$; Yit and $Y j t$ are respectively GDPs of country $i$ and country $j$ in year $t$; sit and sjt are respectively the shares of country $i$ 's GDP and country $j$ 's GDP in their combined GDP in year $t$; Kit/Lit and Kjt/Ljt are respectively the ratios of physical capital to workers in country $i$ and country $j$ in year $t$; Hit/ Lit and Hjt/Ljt are respectively the amounts of human capital per worker in country $i$ and country $j$ in year $t$; DISTANCE $i j$ is a variable measuring the geographical distance between the capitals of country $i$ and country $j$; vij is the individual country-pair specific effect that may be fixed or random; $u t$ is the individual timespecific effect, while eijt is the error term, for $i=$ Poland, $j=1,1 / 4,15$ investment partners of Poland from the old EU-15 countries, and $t=1996,1 / 4,2015$; and a's are the parameters to be estimated. 
Tab. 3: Full sample estimates for the period 1996-2015

\begin{tabular}{|c|c|c|c|c|c|c|}
\hline Explanatory variable & (1) & (2) & (3) & (4) & (5) & (6) \\
\hline H-DIFF & $0.239 * * *(3.20)$ & $0.030(0.34)$ & $0.048(0.56)$ & $0.083(1.22)$ & $-0.003(0.04)$ & $0.015(0.22)$ \\
\hline K-DIFF & $-1.088^{* * *}(5.43)$ & $0.007(0.03)$ & $-0.001(0.01)$ & $-0.507^{*}(1.80)$ & $-0.253(0.89)$ & $-0.293(1.04)$ \\
\hline SDI & $3.891^{* * *}(6.28)$ & $1.075^{* *}(1.97)$ & $1.151^{* *}(2.12)$ & $2.477^{* * *}(3.37)$ & $0.121(0.28)$ & $0.178(0.41)$ \\
\hline SUM & $6.997^{* * *}(21.95)$ & $4.803^{* * *}(15.68)$ & $4.820^{* * *}(15.83)$ & $5.365^{* * *}(5.07)$ & $1.778^{* * *}(4.34)$ & $1.760^{* * *}(4.34)$ \\
\hline DISTANCE & - & - & $-1.416^{* *}(2.25)$ & - & - & $-1.453^{* * *}(2.69)$ \\
\hline Constant & $\begin{array}{l}-73.259^{* * *} \\
(25.49)\end{array}$ & $\begin{array}{l}-58.936^{* * *} \\
(19.28)\end{array}$ & $-48.966^{* * *}(9.06)$ & $-59.540^{* * *}(4.12)$ & $\begin{array}{l}-13.737^{* *} \\
(2.01)\end{array}$ & $-2.628(0.33)$ \\
\hline Time-specific effects & No & No & No & Yes & Yes & Yes \\
\hline Country-specific effects & Fixed & Random & Random & Fixed & Random & Random \\
\hline Overall $R^{2}$ & 0.188 & 0.275 & 0.337 & 0.261 & 0.493 & 0.596 \\
\hline Within $R^{2}$ & 0.765 & 0.724 & 0.726 & 0.841 & 0.833 & 0.833 \\
\hline Between $R^{2}$ & 0.154 & 0.219 & 0.307 & 0.177 & 0.249 & 0.426 \\
\hline $\begin{array}{l}F \text {-test for country-specific effects } \\
(p \text {-val) }\end{array}$ & $83.66(0.000)$ & & & $77.25(0.000)$ & & \\
\hline $\begin{array}{l}\text { LM test for country-specific } \\
\text { effects ( } p \text {-val) }\end{array}$ & & $732.41(0.000)$ & $710.56(0.000)$ & & $1002.34(0.000)$ & $1029.34(0.000)$ \\
\hline Hausman test ( $p$-val) & & $5600.25(0.000)$ & $1110.73(0.000)$ & & $6.37(0.999)$ & $10.94(0.983)$ \\
\hline
\end{tabular}

Notes: $N=300$ in all specifications; ${ }^{*}$ significant at the $10 \%$ level of significance, ${ }^{* *}$ significant at the $5 \%$ level of significance, ${ }^{* * *}$ significant at the $1 \%$ level of significance, and $z$-statistics in parentheses.

Source: own elaboration.

Tab. 4: Limited sample estimates for the pre-accession period 1996-2004

\begin{tabular}{|c|c|c|c|c|c|c|}
\hline Explanatory variable & (1) & (2) & (3) & (4) & (5) & (6) \\
\hline H-DIFF & $0.235(0.87)$ & $-0.033(0.12)$ & $-0.148(0.59)$ & $0.308(1.21)$ & $0.055(0.24)$ & $-0.027(0.13)$ \\
\hline K-DIFF & $-1.437(1.37)$ & $-3.946^{* * *}(4.80)$ & $-4.923^{* * *}(6.54)$ & $-1.084(0.94)$ & $-0.915(0.96)$ & $-1.731 *(1.97)$ \\
\hline SDI & $-0.683(0.33)$ & $-0.619(0.61)$ & $-0.743(0.96)$ & $-1.104(0.56)$ & $-0.642(0.70)$ & $-0.512(0.75)$ \\
\hline SUM & $7.185^{* * *}(7.56)$ & $3.975^{* * *}(6.05)$ & $2.879 * * *(5.90)$ & $7.308^{* * *}(2.63)$ & $1.817^{* * *}(2.70)$ & $1.554^{* * *}(3.21)$ \\
\hline DISTANCE & - & - & $-2.720^{* * *}(3.93)$ & - & - & $-2.140^{* * *}(3.42)$ \\
\hline Constant & $-76.606^{* * *}(3.06)$ & $-2.609(0.16)$ & $43.076 * * *(2.73)$ & $-82.267^{*}(1.92)$ & $-7.431(0.49)$ & $20.986(1.41)$ \\
\hline Time-specific effects & No & No & No & Yes & Yes & Yes \\
\hline Country-specific effects & Fixed & Random & Random & Fixed & Random & Random \\
\hline Overall $R^{2}$ & 0.264 & 0.284 & 0.554 & 0.265 & 0.374 & 0.641 \\
\hline Within $R^{2}$ & 0.696 & 0.664 & 0.628 & 0.750 & 0.738 & 0.734 \\
\hline Between $R^{2}$ & 0.262 & 0.261 & 0.577 & 0.259 & 0.264 & 0.611 \\
\hline $\begin{array}{l}F \text {-test for country-specific effects } \\
(p \text {-val) }\end{array}$ & $52.39(0.000)$ & & & $51.42(0.000)$ & & \\
\hline $\begin{array}{l}\text { LM test for country-specific effects } \\
\text { ( } p \text {-val) }\end{array}$ & & $252.63(0.000)$ & $136.16(0.000)$ & & $350.36(0.000)$ & $214.43(0.000)$ \\
\hline Hausman test ( $p$-val) & & $228.51(0.000)$ & $87.88(0.000)$ & & $12.64(0.396)$ & $17.28(0.139)$ \\
\hline
\end{tabular}

Notes: $N=135$ in all specifications; * significant at the $10 \%$ level of significance, ${ }^{* * *}$ significant at the $1 \%$ level of significance, and $z$-statistics in parentheses.

Source: own elaboration. 
Tab. 5: Limited sample estimates for the post-accession period 2005-2015

\begin{tabular}{|c|c|c|c|c|c|c|}
\hline Explanatory variable & (1) & (2) & (3) & (4) & (5) & (6) \\
\hline H-DIFF & $0.012(0.17)$ & $-0.024(0.36)$ & $-0.009(0.14)$ & $-0.029(0.46)$ & $-0.030(0.46)$ & $-0.018(0.29)$ \\
\hline K-DIFF & $0.354(1.17)$ & $0.405^{*}(1.80)$ & $0.425^{*}(1.89)$ & $-0.646^{*}(1.75)$ & $-0.542(1.44)$ & $-0.520(1.40)$ \\
\hline SDI & $1.596^{* *}(2.45)$ & $0.594(1.23)$ & $0.688(1.41)$ & $-0.076(0.09)$ & $0.469(1.00)$ & $0.539(1.14)$ \\
\hline SUM & $1.232^{* *}(1.97)$ & $0.994 * *(2.55)$ & $0.985^{* *}(2.49)$ & $-1.974(1.39)$ & $0.556(1.13)$ & $0.516(1.03)$ \\
\hline DISTANCE & - & - & $-1.205^{*}(1.89)$ & - & - & $-1.115^{*}(1.73)$ \\
\hline Constant & $-11.711^{* *}(2.13)$ & $-10.050^{* * *}(2.64)$ & $-1.535(0.26)$ & $45.004^{*}(2.12)$ & $6.925(0.82)$ & $16.065(1.62)$ \\
\hline Time-specific effects & No & No & No & Yes & Yes & Yes \\
\hline Country-specific effects & Fixed & Random & Random & Fixed & Random & Random \\
\hline Overall $R^{2}$ & 0.045 & 0.129 & 0.237 & 0.119 & 0.135 & 0.223 \\
\hline Within $R^{2}$ & 0.240 & 0.226 & 0.229 & 0.409 & 0.387 & 0.390 \\
\hline Between $R^{2}$ & 0.037 & 0.119 & 0.238 & 0.191 & 0.112 & 0.206 \\
\hline$F$-test for country-specific effects ( $p$-val) & $65.49(0.000)$ & & & $74.82(0.000)$ & & \\
\hline $\begin{array}{l}\text { LM test for country-specific effects } \\
(p \text {-val) }\end{array}$ & & $367.39(0.000)$ & $404.82(0.000)$ & & $398.08(0.000)$ & $430.19(0.000)$ \\
\hline Hausman test ( $p$-val) & & $1.85(0.763)$ & $3.29(0.510)$ & & $9.26(0.814)$ & $8.48(0.863)$ \\
\hline
\end{tabular}

Notes: $N=165$ in all specifications; * significant at the $10 \%$ level of significance, ** significant at the $5 \%$ level of significance, *** significant at the $1 \%$ level of significance, and $z$-statistics in parentheses.

Source: own elaboration.

\section{Empirical results}

In this section, we present and discuss our estimation results. First, in Table 3, we report estimation results obtained for the full sample. Then, in Table 4, we report estimation results obtained for the sample limited to the pre-accession period 1996-2004. Finally, in Table 5, we report estimation results obtained for the sample limited to the post-accession period 2005-2015.

The benchmark estimation results obtained using the fixed-effects estimator but without controlling for individual time effects are presented in column (1) of Table 3. It turns out that all the estimated coefficients on our explanatory variables are statistically significant already at the $1 \%$ level. The majority of the estimated coefficients display the expected signs that favor the $\mathrm{KC}$ model in which both market access and costreducing motives determine FDI over the pure models of horizontally and vertically integrated multinational firms.

On the one hand, the positive signs of the estimated parameters on the measures of both the relative and the absolute country sizes suggest that FDI increases with the similarity in the market size as well as the size of the combined market in both home and host countries, which is in line with the horizontal motive for FDI. On the other hand, the positive sign of the estimated parameter on the measure of differences in human capital per worker suggests that FDI increases with differences in relative factor endowments between the home and host countries, which is in line with the vertical motive for FDI. However, the negative sign of the estimated parameter on the differences in physical capital per worker would rather suggest the importance of the horizontal motive.

The robustness of the fixed-effects estimates is studied using the random-effects estimator. The random-effects estimates obtained without controlling for individual time effects are presented in column (2) of Table 3. These results differ from the results reported in column (1) as now the estimated parameters on both relative factor endowment variables are not statistically significant at any of the usually accepted levels of statistical significance. The estimated parameter on the 
relative country size becomes now statistically significant only at the 5\% level, while the estimated parameter on the absolute country size remains statistically significant at the $1 \%$ level. Both parameters display expected positive signs meaning that FDI increases with both the similarity in the market size and the size of the combined market in home and host countries, which is in line with the horizontal reason for FDI. However, the Hausman test with $p$-value equal 0.000 favors the fixed-effects estimator as the proper estimation format.

Unfortunately, in the fixed-effects estimation, it is not possible to obtain the estimate of the parameter on the distance variable that does not vary over time and becomes a part of the country-specific fixed effect. Therefore, in order to investigate the sign of the estimated parameter on the distance variable, we also estimate the specification of the model that includes the distance variable using the random-effects estimator. The estimation results obtained from this specification are reported in column (3). The estimated parameter on the distance variable is statistically significant at the 5\% level and displays a negative sign, which is in line with the vertical reason.

In columns (3)-(5), we study the robustness of our previous fixed- and random-effects estimates, respectively, by controlling for individual time-specific effects by including dummy variables for particular years of our sample. The estimated coefficients on time effects in both cases are jointly statistically significant, and their inclusion improves the accuracy of our estimates reported in columns (1)-(3), which is reflected in the higher values of $R^{2} \mathrm{~s}$.

The estimation results obtained via the fixed-effects estimator by controlling for individual time effects, presented in column (4), show that only the estimated parameters on the relative and absolute country sizes are statistically significant at the $1 \%$ level and display the positive signs. The estimated parameter on the differences in physical capital per worker is statistically significant at the $10 \%$ level only and displays a negative sign, while the estimated parameter on the differences in human capital per worker is not statistically significant at all. Hence, these results favor the importance of the horizontal motive.

Subsequently, the estimation results obtained via the random-effects estimator by controlling for individual time effects are presented in column (5). These results show that only the estimated parameter on the combined market size variable is statistically significant at the $1 \%$ level and displays a positive sign. The remaining explanatory variables are not statistically significant at all. The Hausman test with $p$-value equal to 0.999 clearly favors the random-effects estimator as the proper estimation format.

Finally, in column (6), we report estimation results obtained from the specification of the model that includes the distance variable using the random-effects estimator while controlling for individual time effects. These results show that the only explanatory variables that are statistically significant at the $1 \%$ level are the absolute country size and the geographic distance between Poland and investment partner countries. The estimated parameter on the combined market size remains positive, while the estimated parameter on the distance variable is negative. All the other explanatory variables remain statistically not significant. These results are similar to the estimation results obtained on the basis of an ad hoc empirical gravity framework frequently used in previous empirical studies of bilateral FDI flows that included GDPs of the home and host countries and distance between them as the only explanatory variable. Hence, it seems that the estimated KC model does not perform better than the simple gravity model used in many early empirical studies mentioned in the literature review section. ${ }^{3}$

In Tables 4 and 5, we report estimation results obtained for the subsamples limited to the pre-accession period 1996-2004 and the post-accession period 20052015, respectively. The particular columns in Tables 4 and 5 are the direct counterparts of columns in Table 3. In column (1) of Table 4, we show the estimation results obtained for the pre-accession period using the fixedeffects estimator without controlling for individual time effects. These results show that the sum of GDPs is the only statistically significant explanatory variable in addition to the constant term. This reinforces the earlier view that the $\mathrm{KC}$ model does not perform better than the simple ad hoc gravity model.

Subsequently, in column (2) of Table 4, we show the estimation results obtained for the pre-accession period using the random-effects estimator without controlling

3 See, inter alia, Brenton et al. (1999) and Cieślik and Ryan (2004). 
for individual time effects. These results show that in addition to the GDP sum, which remains statistically significant at the $1 \%$ level and displays a positive sign, also the differences in capital to labor ratios are statistically significant at the $1 \%$ level but display a negative sign. However, the Hausman test with the $p$-value equal to 0.000 clearly favors the fixed-effects estimator as the proper estimation format.

Finally, in column (3) of Table 4, we report estimation results obtained from the specification of the model that includes the distance variable using the randomeffects estimator without controlling for individual time effects. These results show that in addition to the GDP sum and the differences in capital to labor ratios that remain statistically significant at the $1 \%$ level, also the geographical distance variable is statistically significant at the $1 \%$ level and displays a negative sign.

The estimation results obtained via the fixed-effects estimator by controlling for individual time effects are presented in column (4) of Table 4. These results show that in qualitative terms, the inclusion of time effects does not change our previous conclusions obtained on the basis of the estimates reported in column (1) as the GDP sum remains the only statistically significant explanatory variable.

Subsequently, in column (5) of Table 4, we show the estimation results obtained via the random-effects estimator by controlling for individual time effects. These results show that, similar to the estimates reported in column (2), the GDP sum remains statistically significant at the $1 \%$ level and displays an expected positive sign. However, this time, the estimated parameter on the differences in capital to labor ratios variable loses its previous statistical significance. Therefore, these estimation results are very similar to the results reported in column (4) that were obtained using the fixed-effects estimator with individual time effects. However, the Hausman test with the $p$-value equal to 0.396 favors the random-effects estimator as the proper estimation format. Therefore, the estimation results obtained for the subsample consisting of the pre-accession years 1996-2004 are very similar to the results obtained for the full sample.

Finally, in column (6) of Table 4, we report estimation results obtained from the specification of the model that includes the distance variable using the random-effects estimator with individual time effects. These results show that, similar to the estimates reported in column (3), the GDP sum, the geographical distance, and the differences in capital to labor ratios are statistically significant and mostly display the expected signs. However, this time, the estimated parameter on the differences in capital to labor ratios variable is statistically significant only at the $10 \%$ level.

In Table 5, we show the estimation results obtained for the subsample containing the post-accession years 2005-2015. In column (1) of Table 5, we report the estimation results obtained for the post-accession period using the fixed-effects estimator without controlling for individual time effects. These results show that the only statistically significant explanatory variables are the GDP sum and the similarity in market size, both at the $5 \%$ level, which support the horizontal reason for FDI.

In column (2) of Table 5, we show the estimation results obtained for the post-accession period using the random-effects estimator without controlling for individual time effects. These results show that in addition to the GDP sum, which remains statistically significant at the 5\% level, also the differences in capital to labor ratios are statistically significant at the $10 \%$ level. Moreover, in contrast to the results reported in column (2) of Table (4), the estimated coefficient on the differences in capital to labor ratios displays now a positive sign, which is in line with the vertical reason for FDI. The Hausman test with the $p$-value equal to 0.763 clearly favors the random-effects estimator as the proper estimation format.

In column (3) of Table 5, we report the estimation results obtained from the specification of the model that includes the distance variable using the randomeffects estimator without controlling for individual time effects. These results show that in addition to the GDP sum and the differences in capital to labor ratios, also the geographical distance is statistically significant at the $10 \%$ level and displays the negative sign.

The estimation results obtained via the fixed-effects estimator by controlling for individual time effects are shown in column (4) of Table 5. Compared to the results reported in column (1) after the inclusion of time effects, the GDP sum and the similarity in market size variables are no longer statistically significant. The only statistically significant explanatory variable, but only at 
the $10 \%$ level, is now the difference in capital to labor ratios, which displays a negative sign.

Subsequently, in column (5) of Table 5, we show the estimation results obtained via the random-effects estimator by controlling for individual time effects. However, in this case, none of the explanatory variables is statistically significant, while the Hausman test with the $p$-value equal to 0.814 favors the random-effects estimator as the proper estimation format.

Finally, in column (6) of Table 5, we report the estimation results obtained via the random-effects estimator by controlling for individual time effects. In this case, the only statistically significant explanatory variable, but only at the $10 \%$ level, is now the distance variable, which displays a negative sign. Hence, the estimates obtained for the sub-sample consisting of the post-accession years show that the KC model does not contribute to the better understanding of FDI determinants compared to the simple ad hoc gravity model with geographic distance between the investment partners as the key explanatory variable.

\section{Conclusions}

This study used the panel data analysis to examine empirically the horizontal and vertical reasons for FDI from the old EU-15 member states in Poland during the period 1996-2015. The estimated specification of the empirical model was derived from the modified KC model with two types of capital: human and physical, in which both horizontally and vertically integrated multinational firms could coexist in equilibrium. The assembled empirical evidence pointed to the horizontal rather than the vertical motive as the main reason for FDI in Poland. However, the modified KC model does not seem to explain the cross-country pattern of inward FDI in Poland better than the traditional ad hoc gravity model that relates bilateral FDI only to GDPs of investment partners and distance between them.

Therefore, in future studies, it would be useful to extend the sample and include source countries other than the old EU-15 countries. Moreover, in future studies, it would be recommended to reestimate the specifications using another dependent variable that would better measure the extent of multinational involvement in the host country. In particular, the FDI variable could be limited only to the net sum of foreign equity, while the debt instruments would be excluded from the FDI position as this variable would better correspond to the postulated theoretical relationship. Unfortunately, the NBP started to report the data for these two categories only relatively recently. Therefore, this issue needs to be addressed in future studies.

\section{Acknowledgement}

This paper is the outcome of the research project no. 2015/19/B/HS4/03230 entitled "Determinants of Foreign Direct Investment in Poland" financed by National Science Centre conducted by Andrzej Cieślik in the years 2016-2018. The author wishes to thank Sabina Szymczak, Farid Toubal, the participants of WIEM conference, and two anonymous reviewers for their helpful comments, suggestions, and discussions on the previous draft of this paper.

\section{References}

[1] Ascani, A., Crescenzi, R., \& Iammarino, S. (2017). The geography of foreign investments in the EU neighbourhood. Tijdschrift Voor Economische En Sociale Geografie, 108(1), 76-91.

[2] Baniak, A., Cukrowski, J., \& Herczyński, J. (2005). On the determinants of foreign direct investment in transition economies. Problems of Economic Transition, 48(2), 6-28.

[3] Benacek, V., Gronicki, M., Holland, D., \& Sass, M. (2000). The determinants and impact of foreign direct investment in Central and Eastern Europe: A comparison of survey and econometric evidence. Transnational Corporations, 9(3), 163-212.

[4] Bergstrand, J. H., \& Egger, P. (2007). A knowledge and physical capital model of international trade flows, foreign direct investment and multinational enterprises. Journal of International Economics, 73(2), 278-308.

[5] Bergstrand, J. H., \& Egger, P. (2013). Shouldn't physical capital also matter for multinational 
enterprise activity? Review of International Economics, 21(5), 945-965.

[6] Bevan, A. A., \& Estrin, S. (2004). The determinants of foreign direct investment into European transition economies. Journal of Comparative Economics, 32(4), 775-787.

[7] Bloningen, B. A., Davies, R. B., \& Head, K. (2003). Estimating the knowledge capital model of the multinational enterprise: Comment. The American Economic Review, 93(3), 980-994.

[8] Braconier, H., Norback, H. P. J., \& Urban, D. (2005). Reconciling the evidence on the knowledge-capital model. Review of International Economics, 13(4), 770786.

[9] Brainard, L.S. (1993a). A simple theory of multinational corporations and trade with a tradeoff between proximity and concentration. NBER Working Paper 4269.

[10] Brainard, L. S. (1993b). An empirical assessment of the factor proportions explanation of multinational sales. NBER Working Paper 4580.

[11] Brainard, L. S. (1997). An empirical assessment of the proximity concentration tradeoff between multinational sales and trade. The American Economic Review, 87(4), 520-544.

[12] Brenton, P., Di Mauro, F., \& Lucke, M. (1999). Economic integration and FDI: An empirical analysis of foreign investment in the EU and in Central and Eastern Europe. Empirica, 26(2), 95-121.

[13] Carr, D. L., Markusen, J. R., \& Maskus, K. E. (2001). Estimating the knowledge capital model of the multinational enterprise. The American Economic Review, 91(3), 693-708.

[14] Carr, D. L., Markusen, J. R., \& Maskus, K. E. (2004). Competition for multinational investment in developing countries: Human capital, infrastructure and market size. In R. E. Baldwin \& A. L. Winters (Eds.), Challenges to globalization: analyzing the economics (pp. 383-409). Chicago, IL: University of Chicago Press.

[15] Carstensen, K., \& Toubal, F. (2004). Foreign direct investment in Central and Eastern European countries: A dynamic panel analysis. Journal of Comparative Economics, 32(1), 3-22.

[16] CentralStatistical Office. (2015). The economic activity of firms with foreign capital participation. Warszawa, Poland: Zakład Wydawnictw Statystycznych.
[17] Chen, Y., Horstmann, I. J., \& Markusen, J. R. (2012). Physical capital, knowledge capital, and the choice between FDI and outsourcing. The Canadian Journal of Economics, 45(1), 1-15.

[18] Cieślik, A. (1996). FDI in Central Europe's Transition: Early Results, Discussion Paper 28, Faculty of Economic Sciences, Warsaw University.

[19] Cieślik, A. (2006). Why do multinational firms invest in Poland? Horizontal vs. vertical FDI. In The influence of the globalisation processes on central and Eastern European Region (pp. 379-390). Sopot, Poland: Gdańsk University Press.

[20] Cieślik, A. (2007). The impact of free trade agreements on Poland's foreign trade in 1992-2004. Bank $i$ Kredyt, 38(6), 3-23.

[21] Cieślik, A. (2013). Horizontally integrated MNE and plant heterogeneity. Bank $i$ Kredyt, 44(6), 605622.

[22] Cieślik, A. (2015a). North-North FDI, exporting and the first mover advantage. Bank $i$ Kredyt, 46(2), 109-128.

[23] Cieślik, A. (2015b). Imperfect competition, productivity differences and proximityconcentration trade-offs. Ekonomia, 40, 7-30.

[24] Cieślik, A. (2016). Exports versus FDI in SmithMotta framework. Equilibrium. Quarterly Journal of Economics and Economic Policy, 11(2), 189-218.

[25] Cieślik, A. (2017). Determinants of MNE activity in Poland: the case of firms from EU-15. Entrepreneurial Business and Economics Review, 5(1), 151-167.

[26] Cieślik, A. (2018). Leader-follower model of reciprocal FDI and international trade. Argumenta Oeconomica, 41(2), 91-112.

[27] Cieślik, A. (2019a). MNE activity in Poland: Horizontal, vertical or both? Emerging Markets Finance and Trade, forthcoming, doi:10.1080/15404 96X.2018.1549029.

[28] Cieślik, A. (2019b). What attracts multinational enterprises from the new EU member states to Poland? Eurasian Business Review, forthcoming, doi:10.1007/s40821-019-00122-z.

[29] Cieślik, A. (2019c). Determinants of foreign direct investment from OECD countries in Poland. Eurasian Economic Review, forthcoming, doi:10.1007/s40822-019-00136-y. 
[30] Cieślik, A., \& Hagemejer, J. (2011). Evaluating the effectiveness of preferential trade liberalization in Central and Eastern Europe'. The International Trade Journal, 25(5), 516-538.

[31] Cieślik, A., \& Ryan, M. (2004). Explaining Japanese direct investment flows into an enlarged Europe: A comparison of gravity and economic potential approaches. Journal of the Japanese and International Economies, 18(1), 12-37.

[32] Cieślik, A., \& Ryan, M. (2012). Productivity differences and foreign market entry in an oligopolistic industry. Open Economies Review, 23(3), 531-557.

[33] Collie, D. R. (2011). Multilateral trade liberalization, foreign direct investment and the volume of world trade. Economics Letters, 113(1), 47-49.

[34] Davies, R. B. (2008). Hunting high and low for vertical FDI. Review of International Economics, 16(2), 250-267.

[35] Feenstra, R. C., Inklaar, R., \& Timmer, M. P. (2015). The next generation of the Penn World Table. The American Economic Review, 105(10), 3150-3182.

[36] Garibaldi, P., Mora, N., Sahay, R., \& Zettelmeyer, J. (2001). What moves capital to transition economies? IMF Staff Papers, 48, 109-145.

[37] Gorbunova, Y., Infante, D., \& Smirnova, J. (2012). New evidence on FDI determinants: An appraisal over the transition period. Prague Economic Papers, 2, 129-149.

[38] Helpman, E. (1984). A simple theory of trade with multinational corporations. Journal of Political Economy, 92(3), 451-471.

[39] Helpman, E. (1987). Imperfect competition and international trade: Evidence from fourteen industrial countries. Journal of the Japanese and International Economies, 1(1), 62-81.

[40] Helpman, E., \& Krugman, P. (1985). Market structure and foreign trade: Increasing returns, imperfect competition and the international economy. Cambridge, MA: MIT Press.

[41] Helpman, E., Melitz, M. J., \& Yeaple, S. R. (2004). Export versus FDI with heterogeneous firms. The American Economic Review, 94(1), 300-316.

[42] Horstmann, I., \& Markusen, J. R. (1987). Strategic investments and the development of multinationals. International Economic Review, 28(1), 109-121.
[43] Krugman, P. (1983). The 'New Theories' of international trade and multinational enterprise. In D. B. Audretsch \& Ch.P Kindleberger (Eds.), The multinational corporation in the 1980s (pp. 57-73). Boston, MA: MIT Press.

[44] Lansbury, M., Pain, N., \& Smidkova, K. (1996). Foreign direct investments in Central Europe since 1990: An econometric study. National Institute Economic Review, 156, 104-113.

[45] Markusen, J. R. (1984). Multinationals, multi-plant economies and the gains from trade. Journal of International Economics, 16(3-4), 205-226.

[46] Markusen, J. R. (2002). Multinational firms and the theory of international trade. Cambridge, MA: MIT Press.

[47] Markusen, J. R. (2013). Multinational firms. In D. Bernhofen, R. Falvey, D. Greenaway, \& U. Kreickemeier (Eds.), Palgrave handbook of international trade London, England: Palgrave Macmillan.

[48] Markusen, J. R., \& Stähler, F. (2011). Endogenous market structure and foreign market entry. Review of World Economics, 147(2), 195-215.

[49] Markusen, J. R., \& Strand, B. (2009). Adapting the knowledge-capital model of the multinational enterprise to trade and investment in business services. The World Economy, 32(1), 6-29.

[50] Markusen, J. R., \& Venables, A. J. (1998). Multinational firms and the new trade theory. Journal of International Economics, 46(2), 183-203.

[51] Markusen, J. R., \& Venables, A. J. (2000). The theory of endowment, intra-industry and multinational trade. Journal of International Economics, 52(2), 209234.

[52] Sinha, U. B. (2010). Strategic licensing, exports, FDI, and host country welfare. Oxford Economic Papers, 62(1), 114-131.

[53] Stack, M. M., Ravishankar, G., \& Pentecost, E. (2017). Foreign direct investment in eastern European countries: Determinants and performance. Structural Change and Economic Dynamics, 41, 86-97.

[54] Tang, D. (2017). The determinants of European Union (EU) foreign direct investments in the EU countries from Central and Eastern Europe during 1994-2012. Comparative Economic Research, 20(1), 75-99. 
[55] Torrisi, C. R., Delaunay, C. J., Kocia, A., \& Lubieniecka, M. (2009). FDI in Poland: Determinants and implications for countries in transition. Ekonomia, 23, 3-15.

[56] Wach, K., \& Wojciechowski, L. (2016). Determinants of inward FDI into Visegrad countries: Empirical evidence based on panel data for the years 20002012. Economics and Business Review, 2(1), 34-52.

[57] Zhang, K. H., \& Markusen, J. R. (1999). Vertical multinationals and host-country characteristics. Journal of Development Economics, 59(2), 233-252. 